\title{
Amounts of discards by commercial fisheries and their significance as food for seabirds in the North Sea
}

\author{
Stefan Garthe ${ }^{1,2,}$, Kees (C. J.) Camphuysen ${ }^{3}$, Robert W. Furness ${ }^{4}$ \\ ${ }^{1}$ Institut für Vogelforschung 'Vogelwarte Helgoland', Inselstation, PO Box 1220, D-27494 Helgoland, Germany \\ ${ }^{2}$ Institut für Meereskunde, Abt. Meereszoologie, Düsternbrooker Weg 20, D-24105 Kiel, Germany \\ ${ }^{3}$ Netherlands Institute for Sea Research, PO Box 59, 1790 AB Den Burg, The Netherlands \\ ${ }^{4}$ Applied Ornithology Unit, Institute of Biomedical and Life Sciences, University of Glasgow, Glasgow G12 8QQ, United Kingdom
}

\begin{abstract}
Most types of fishery produce discards and offal in considerable quantities which are fed upon by seabirds. This paper demonstrates the importance to seabirds of fishery waste in the North Sea. The total amount of fishery waste in the North Sea region is estimated at $62800 \mathrm{t}$ of offal, $262200 \mathrm{t}$ of roundfish, $299300 \mathrm{t}$ of flatfish, $15000 \mathrm{t}$ of elasmobranchs and $149700 \mathrm{t}$ of benthic invertebrates per year, representing $4 \%$ of the total biomass of fish and $22 \%$ of the total landings. This equals an energy value of about $3.4 \times 10^{12} \mathrm{~kJ}$. Beam trawl fisheries discharge discards at the highest rates of all fishing fleets. Their discard fraction is dominated by flatfish which are less favoured by seabirds because of their shape. In contrast, the amounts of discards from pelagic and gadid fisheries are less, but fish species and lengths are more appropriate as food for seabirds. The number of seabirds potentially supported by fishery waste in the North Sea is estimated to be roughly 5.9 million individuals in an average scavenger community (composition in proportion to the seasonal abundance of scavenging species). During experimental discard studies, the proportions of fishery waste consumed by seabirds was calculated. We estimated that the mass of discards and offal consumed by birds during our study amounted to $55000 \mathrm{t}$ of offal, $206000 \mathrm{t}$ of roundfish, $38000 \mathrm{t}$ of flatfish, $2000 \mathrm{t}$ of elasmobranchs and 9000 t of benthic invertebrates.
\end{abstract}

KEY WORDS: Fisheries · Discards · Offal - Seabirds · Food · Energy requirements - North Sea

\section{INTRODUCTION}

Discarding unwanted parts of the catch has been common practice since the beginning of fisheries. However, by the end of the 19 th century, people were becoming concerned about the waste of this valuable resource. For example, Weigelt (1891) investigated the nature, amount, use and exploitation of fishery waste produced by German fisheries. During the second half of the 20th century, with a rapid increase in fishing effort, these concerns increased because large proportions of young fish of commercial species were killed (e.g. Sahrhage 1958, 1959). Additionally, the influence or fisheries is of interest to other biologicai and envi-

•E-mail: sgarthe@ifm.uni-kiel.d400.de ronmental sciences that focus on the effects of human activities on other aspects of the environment.

The availability of large amounts of discards and offal is one of the factors which may have contributed to the rapid growth of some seabird populations (e.g. Dunnet et al. 1990, Lloyd et al. 1991). Large-scale studies in the North Sea have demonstrated that scavenging seabirds make extensive use of fishery waste, above all of offal and roundfish, but also to some extent of flatfish, cephalopods and benthic invertebrates (Camphuysen et al. 1993, 1995). The proportions of discards and offal seasonally consumed by seabirds are relatively well known for the North Sea as a whole. in order to caicuiate the totai number of seabiras winich could be sustained by this food supply, data on the amount of discards and on the energetics of seabirds 
are needed. Information on discards is available for some fisheries (e.g. beam trawl, gadid and pelagic fisheries) while for others the information is lacking (set net and industrial fisheries). The shrimp fishery and other near-coastal fisheries are omitted from these analyses because those areas are occupied by seabird communities that differ from the pelagic community addressed here and because the composition of the discards deviates considerably from that of offshore fisheries. Seabird energetics have been studied sufficiently to enable approximations of seabird energy demands in the North Sea (e.g. Birt-Friesen et al. 1989, Anonymous 1994d, Bryant \& Furness 1995).

Here, we estimate the amount of discards and offal discharged by commercial fisheries, the proportion consumed by seabirds and the number of seabirds potentially sustained by this type of food. This information is valuable since it is expected that future developments of North Sea fisheries will lead to a reduction of fishing effort and/or fish biomass caught, followed consequently by a reduction or change in the amounts and type of fish discarded (e.g. Furness 1992, Hubold 1994). We thus also consider possible effects of a shortened food supply on the scavenging species breeding along the North Sea coast.

\section{METHODS}

This paper is based upon data obtained during a study of scavenging seabirds in the North Sea (Camphuysen et al. 1995) and a comprehensive review of information in the fisheries literature on the quantities of fish, benthos and offal discarded in the North Sea. Field studies of scavenging seabirds were carried out from February 1994 to March 1995. The distributions, abundances and feeding behaviour of scavenging seabirds were investigated from fishery research vessels engaged in the International Bottom Trawl Survey' (IBTS; Anonymous 1990) during all 4 seasons (winter: January/February 1993, spring: April/May 1994, summer: August/September 1994, autumn: October/November 1994)

We define as 'discards' fish and invertebrates which are caught at sea and which are subsequently discharged again because they (1) are too small to be commercially exploited, (2) are below the official minimum landing size, (3) belong to a species for which there is no demand or (4) are caught in excess of the fishing quota. 'Offal' is defined as the livers and intestines of marketable fish that have been removed during fish sorting and cleaning (Hudson \& Furness 1988).

The amounts of discards and offal and their calorific values were estimated from published data. If not given in the literature, we estimated discard totals. In the last few years some data about discards have been published both by fishery and seabird biologists, but few specific studies have been conducted (reviewed e.g. in Anonymous 1994e, Weber 1995). Hence it was impossible to obtain data of sufficient quality for all fishery types in the North Sea. In this paper, we also omit the coastal zone. Hence, the shrimp fishery restricted to the Wadden Sea area is not included although extensive data on discards have been compiled there (Tiews 1983, Berghahn 1990, Tiews \& Wienbeck 1990, Walter \& Becker 1994). The most recent statistics on landings originate from 1988 (Anonymous 1992). Therefore, landings data were estimated for 1992 on the basis of ICES working groups reports (see Table 1 for sources).

For quantifying the amount of offal discarded in all fisheries we assumed that it represents a constant proportion of the landed mass of each species, following Anonymous (1994e). Our estimate for 1992 is based on statistics of all demersal fish landed from the North Sea (see Table 1 for sources). Offal originating from dab, flounder, plaice, sole, turbot Psetta maxima and witch Glyptocephalus cynoglossus were assigned to beam trawl fisheries, offal originating from other species were assigned to non-beam trawl fisheries (see Table 1 for scientific names of fish species).

For discards in pelagic fisheries, no absolute figures are given. Because of incomplete coverage, Corten (1991) did not give any estimates of the total amount of discards in Dutch pelagic fisheries. Although the data are few, a ratio of discards per unit mass of herring caught was derived by summing all catch data listed for the North Sea in Corten (1991)

Kirkegaard (1991) gives percentages of discards per mass unit of target fish (herring, mackerel) caught in Danish pelagic fisheries. There are some differences between seasons and fishing gear (trawl, purse seine). For calculations, we used an average of $5 \%$ discards if herring were caught and $20 \%$ discards for mackerel.

The calorific values of discards and offal vary considerably with time of year, fish length (e.g. Hislop et al. 1991 ) and study. Hence, it was impossible to obtain precise values for all organisms or occasions during the experimental discarding sessions. Table 2 lists the energetic equivalents employed in this study.

Assimilation efficiency in seabirds varies according to the food eaten: from Jackson (1986), Castro et al. (1989) and Brekke \& Gabrielsen (1994) we obtained efficiences of $75 \%$ for fish and offal and $65 \%$ for invertebrates.

Bryant \& Furness (1995) measured basal metabolic rates (BMR) for 11 species of Scottish seabird, ranging in size from the black-legged kittiwake to the northern gannet (see Table 6 for scientific names of bird spe- 
Table 1. Estimated biomasses and landings of fish species in the North Sea. Only species with a biomass of $\geq 50000 t$ are listed. Landings of saithe, mackerel and horse mackerel include the Skagerrak, landings of herring include the Channel. Biomass estimates of herring include the Skagerrak. In all cases, the additional subareas represent only a minor proportion of the total value

\begin{tabular}{|c|c|c|c|c|}
\hline Species & Biomass $\left(\times 10^{3} \mathrm{t}\right)$ & Source & Landings $\left(\times 10^{3} \mathrm{t}\right)$ & Source \\
\hline Herring Clupea harengus & 3428 & 3 & 550 & 3 \\
\hline Sandeels Ammodytes sp. and others & 2081 & 4 & 763 & 2 \\
\hline Dab Limanda limanda & 1620 & 4 & 7 & 6 \\
\hline Horse mackerel Trachurus trachurus & 1585 & 4 & 112 & 5 \\
\hline Mackerel Scomber scombrus & 720 & 4 & 341 & 5 \\
\hline Haddock Melanogrammus aeglefinus & 559 & 1 & 48 & 1 \\
\hline Plaice Pleuronectes platessa & 532 & 1 & 149 & 1 \\
\hline Norway pout Trisopterus esmarcki & 527 & 2 & 183 & 2 \\
\hline Whiting Merlangius merlangus & 390 & 1 & 46 & 1 \\
\hline Saithe Pollachius virens & 315 & 1 & 93 & 1 \\
\hline Cod Gadus morhua & 310 & 1 & 96 & 1 \\
\hline Sprat Sprattus sprattus & 252 & 4 & 102 & 3 \\
\hline Starry ray $R$ aja radiata & 252 & 4 & 5 & $6^{d}$ \\
\hline Long rough dab Hippoglossoides platessoides & 241 & 4 & 0 & 6 \\
\hline Lemon sole Microstomus kitt & 226 & 4 & 6 & 6 \\
\hline Grey gurnard Eutrigla gurnardus & 146 & 4 & 39 & $6^{\mathrm{b}}$ \\
\hline Blue whiting Micromesistius poutassou & 131 & 4 & 34 & 6 \\
\hline Sole Solea solea & 91 & 1 & 33 & 1 \\
\hline Thornback ray Raja clavata & 86 & 4 & 0 & 6 \\
\hline Poor cod Trispoterus minutus & 55 & 4 & 0 & 6 \\
\hline Other species & 502 & 4 & 62 & 6 \\
\hline Total & 14049 & & 2669 & \\
\hline \multicolumn{5}{|l|}{ aAll skate and ray species. ${ }^{b}$ All gurnard species } \\
\hline \multicolumn{5}{|c|}{$\begin{array}{l}\text { Sources: (1) Anonymous (1994a), mean values for } 1990-1992 ;(2) \text { Anonymous (1994b), mean values for } 1990-1992 ;(3) \text { Anony- } \\
\text { mous (1994c), mean values for } 1990-1992 ; \text { (4) Sparholt (1990), mean values for } 1983-1985 \text { of the higher of } 2 \text { estimates; (5) } \\
\text { Anonymous (1993b), mean values for } 1990-1992 ;(6) \text { Anonymous (1992) }\end{array}$} \\
\hline
\end{tabular}

cies). From these measurements they derived the following equation for BMR of North Sea seabirds: BMR $\left(\mathrm{kJ} \mathrm{d}^{-1}\right)=2.30$ (body mass) ${ }^{0.774}$. BMR covers only a part of the energy expenditure of birds. The total costs are encompassed in the field metabolic rate (FMR), which includes energy costs of thermoregulation, digestion, moult, reproduction and activity. Following Anonymous (1994d), we used an FMR of 3.9 BMR during the

Table 2. Energetic equivalents employed in this study of discarded organisms. Equivalents were derived from values provided by Cummins \& Wuycheck (1971), Daan (1975), Furness et al. (1988), Hislop et al. (1991) and Sidwell (1981)

\begin{tabular}{|lc|}
\hline Type of discard & Energetic equivalent $\left(\mathrm{kJ} \mathrm{g}^{-1}\right)$ \\
\hline Offal & 9 \\
Clupeid & 6.5 \\
Mackerel & 6.5 \\
Gadids & 4 \\
Other' roundfish & 4 \\
Flatfish & 4 \\
Elasmobranchs & 4 \\
Clusiaceaiis & 3.5 \\
Echinoderms & 2 \\
Molluscs & 1.5 \\
\hline
\end{tabular}

breeding season (= spring, surveys were carried out mainly in April/May) and 2.5 BMR during other periods of the year (winter, summer and autumn).

Here, we define an 'average scavenger community' as the typical composition of those 8 common seabird species known to consume fishery waste regularly. It is calculated in proportion to the numerical and seasonal abundance of the species in the North Sea.

Anonymous (1994d) listed mean densities for all common seabirds per month and subregion in the North Sea. From those data we calculated totals of the scavenging species per subregion and month and multiplied these figures with the energetic requirements of the respective species, correcting for assimilation efficiency. These energetic requirements are compared with the energy equivalents of the discard totals.

In field studies (Camphuysen et al. 1995), fishery research vessels engaged in the IBTS (Anonymous 1990) were joined by ornithologists during all 4 seasons. Fresh subsamples of the catch consisting of roundfish, flatfish, elasmobranchs, offal and benthic invertebrates were taken from each haul to be used for experimental discarding. Items were identified, measured to the nearest $\mathrm{cm}$ in length and thrown overboard singly from the stern of the vessel. Attempts by 
seabirds to pick up and swallow the item were recorded, noting the species and (if possible) age class of the bird and whether the item was consumed, dropped or stolen. If it was stolen or dropped, the same notes were made for the second and subsequent birds. until the item was finally lost (sunk) or swallowed. Experimental discarding was usually conducted when vessels were stationary as the net was lifted and brought on deck, during discarding the bulk of the catch by the vessel's crew, and also occasionally during towing or steaming

\section{RESULTS}

\section{Quantities of discards}

The 3 main sources of discards and offal in the North Sca were dcmorsal trawlers and seiners catching gadids, pelagic trawlers and seiners and beam trawlers. Comparatively small amounts of discards and offal are produced by the Nephrops fishery, as is also true of set net and long-line fisheries (Kirkegaard \& Poulsen 1990, Camphuysen et al. 1995). Industrial fisheries are expected to produce no offal and only few discards, because they usually keep all the fish caught onboard, but the leakage of fish when the catch is pumped onboard must be an important, but unquantified, source of food for seabirds.

In all commercial fisheries, intestines and livers are removed from marketable roundfish and flatfish and the offal is discarded, except in some Norwegian vessels which have found a market for byproducts (Camphuysen et al. 1995). About 62800 t was discharged into the North Sea in 1992 (11000 t in beam trawl fisheries, $51800 \mathrm{t}$ in other fisheries).

The beam trawl fishery is the dominant fishery in the southern and southeastern North Sea. It is carried out mainly by Dutch trawlers, with lesser effort by Belgian, German and UK vessels (Anonymous 1993a). The main target species is sole, but plaice and other flatfish species are also of commercial interest. The heavy gear used by these ships penetrates considerably into the sediment and the unwanted proportion of the catch is therefore high. Recently, some studies have focused on the amount and type of discards in this fishery. The most recent study (Fonds 1994) estimated a total of $270000 \mathrm{t}$ of dead fish discards and $120000 \mathrm{t}$ of dead invertebrates in 1992 for the sole fishery in the southern North Sea. This figure comes close to the $260000 \mathrm{t}$ of fish discards estimated by van Beek (1990) for 1989 and 1990. Expressed as a ratio, this fishery produced between 6 and $10 \mathrm{~kg}$ of fish discards per $\mathrm{kg}$ of sole landed in the late 1980 s and early 1990s. Assuming a proportion of $93 \%$ of flatfish and $7 \%$ of roundfish in the discards (Garthe 1993), totals of $19000 \mathrm{t}$ of roundfish and 251000 t of flatfish result from the total. given by Fonds (1994).

Demersal fisheries for gadids are carried out by all North Sea coastal nations, with various gear. Based on regular sampling of the Scottish seine, trawl and light trawl fisheries, the Roundfish Working Group has estimated that $56000 \mathrm{t}$ of haddock and $36000 \mathrm{t}$ of whiting has been discarded yearly between 1991 and 1993 by North Sea fisheries for gadids (Anonymous 1995). The amounts were much higher in the 1970 s and also in the first half of the 1980s, and have declined due to the reduction of many gadid stocks in the North Sea (cf. Daan et al. 1990). Knowledge about other commercially exploited species in these fisheries is incomplete. Van Beek (1990) estimated $7800 \mathrm{t}$ of cod and $4700 \mathrm{t}$ of plaice was discarded by Dutch otter and pair trawl demersal fisheries in 1989/1990. From the data of van Beek (1990), Kirkegaard \& Poùsen (1990), Ehrich (1994) and the total landings in the North Sea, we estimate that about $15000 \mathrm{t}$ of cod and about $10000 \mathrm{t}$ of plaice is discarded annually by demersal fisheries for gadids.

Further data are given by Jensen et al. (1994) for discards of fish species of little economic interest in Scottish and Danish demersal trawl and seine fleets. They come to $22900 \mathrm{t}$ of discards on average for 1990 to 1991. Extrapolating the Scottish and Danish data to the whole North Sea by a factor of 2.1 as suggested by Jensen et al. (1994), $15000 \mathrm{t}$ of roundfish (chiefly grey gurnard and norway pout), $23000 \mathrm{t}$ of flatfish (chiefly dab, long rough dab and lemon sole) and $10000 \mathrm{t}$ of elasmobranchs (chiefly starry ray) was discarded on average in 1990 and 1991 by demersal trawl and seine fisheries.

Pelagic fisheries by trawlers and seiners have been studied little with regard to discards. The only published data which allow some extrapolation for the North Sea originate from Corten (1991) for Dutch trawlers and Kirkegaard (1991) for Danish trawlers, both of which were fishing for herring and mackerel.

According to the data given by Corten (1991), $38 \mathrm{~kg}$ of discards (chiefly undersized makerel, herring and saithe) result per $1000 \mathrm{~kg}$ of marketable herring. Due to fisheries policy during the sampling period, Corten (1991) did not believe that the discarding performed by the crew was typical for the whole fleet. Therefore, he supposed that higher amounts of discards are produced when observers do not take part on cruises.

In general, very little or no discards of species other than the target species were observed (Kirkegaard 1991). Consequently, the amount of discards was estimated on the basis of catch data for 1990-1992 (Anonymous 1994c, 1993b) at 95000 t (27000 t of herring and $68000 \mathrm{t}$ of mackerel\}. 
Table 3. Proportion of the fleet of beam trawlers and nonbeam trawlers in 6 subregions in the North Sea (from Camphuysen et al 1995, modified). See Fig. 1 for locations of subregions

\begin{tabular}{|lcc|}
\hline Subregion & Beam trawlers $(\%)$ & Non-beam trawlers (\%) \\
\hline NW & 0.9 & 22.5 \\
NE & 1.5 & 21.8 \\
CW & 3.9 & 10.7 \\
C & 21.0 & 18.1 \\
CE & 23.7 & 18.1 \\
S & 49.0 & 8.8 \\
\hline
\end{tabular}

The Nephrops fishery ( $N$. norvegicus, Crustacea: Astacura) in the North Sea is concentrated off the northeast of England. As in the sole fishery, the target species comprises only a small part of the whole catch. Evans et al. (1994) estimated that Nephrops landings represented only $12 \%$ of the total catch mass. They calculated that $7.7 \mathrm{~kg}$ of fish and invertebrates is discarded per $\mathrm{kg}$ of Nephrops landed (some fish caught were also landed). Based on the calculation by Evans et al. (1994) and the total catch of $9852 \mathrm{t}$ of Nephrops in the North Sea in 1988 (Anonymous 1992), a total of $26200 \mathrm{t}$ of roundfish, $15300 \mathrm{t}$ of flatfish, $5000 \mathrm{t}$ of elasmobranchs and 29700 t of invertebrates (incl. undersized and damaged Nephrops) discards is produced annually.

Beam trawl fisheries, which produce about half the discards and offal discharged into the North Sea, are concentrated in the southern and southeastern North Sea. Systematic surveys in 1994 showed that $93.5 \%$ of all beam trawlers are concentrated in the Southern Bight, Central North Sea and German Bight (Table 3; Camphuysen et al. 1995). Because beam trawlers are easily separated from all other types of fishing vessels, and because the composition of discards in beam trawl fisheries is quite different from that in other fisheries, the amount of discards reported in this article was split into 6 subregions of the North Sea on the basis of the

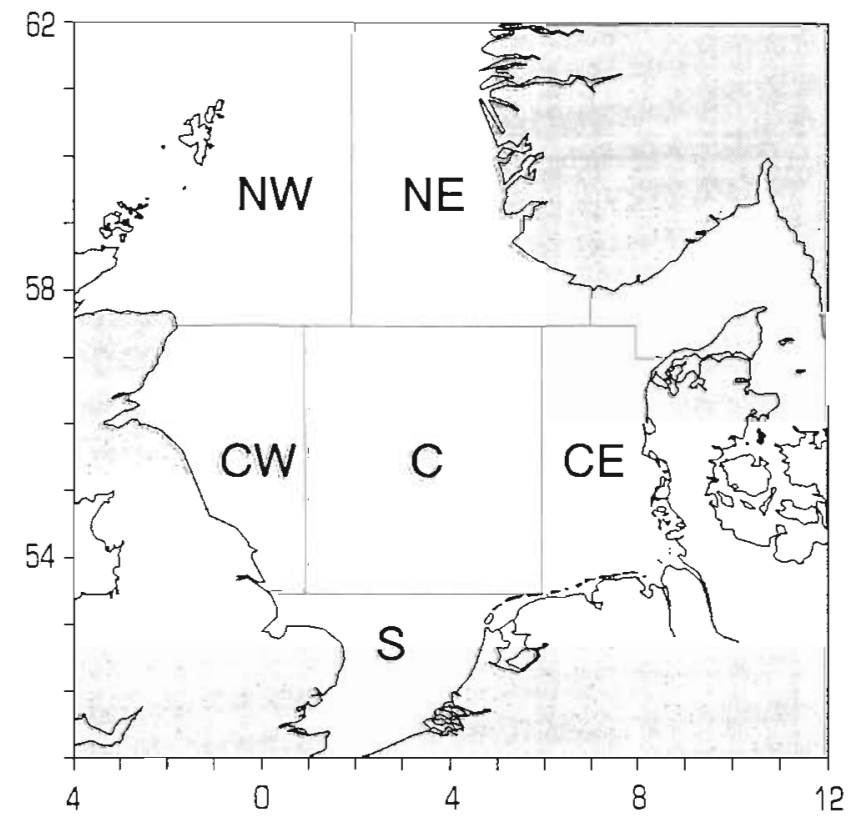

Fig. 1. Map of the 6 subregions in the North Sea

presence of beam trawlers and non-beam trawlers (Table 4. Fig. 1). Due to the geographical distribution of beam trawl fisheries and their huge amounts of discards, the highest density of all discards $\left(4.06 \mathrm{t} \mathrm{km}^{-2}\right.$ $\mathrm{yr}^{-1}$ ) is available in subregion $\mathrm{S}$, the lowest density $\left(0.58 \mathrm{t} \mathrm{km}^{-2} \mathrm{yr}^{-1}\right)$ in subregion NW (Fig. 2).

\section{Number of seabirds potentially supported by fishery waste}

The total amount of discards and offal in the North Sea in 1990 was estimated at $62800 \mathrm{t}$ of offal, $262200 \mathrm{t}$ of roundfish, $299300 \mathrm{t}$ of flatfish, $15000 \mathrm{t}$ of elasmobranchs and $149700 \mathrm{t}$ of benthic invertebrates (Table 4). Converted into energy values, this can be considered as the amount of fishery waste on which scavenging animals can theoretically be sustained.

Table 4. Estimated quantities of discards and offal in 6 subregions in the North Sea in 1990 (in tonnes). For assumptions and sources see text

\begin{tabular}{|lrrrrrr|}
\hline Subregion & Roundfish & Flatfish & Elasmobranchs & $\begin{array}{c}\text { Benthic } \\
\text { invertebrates }\end{array}$ & Offal \\
\hline NW & 54890 & 13130 & 3380 & 7760 & 11750 & 90910 \\
NE & 53310 & 14290 & 3270 & 8270 & 71450 & 90590 \\
CW & 26760 & 14960 & 1610 & 7860 & 5970 & 57160 \\
C & 48010 & 61450 & 2710 & 30580 & 11690 & 154440 \\
CE & 48520 & 68230 & 2710 & 61410 & 9950 & 165270 \\
S & 30710 & 127240 & 1320 & 149700 & 62800 & 789000 \\
Total & 262200 & 299300 & 15000 & & & \\
\hline
\end{tabular}




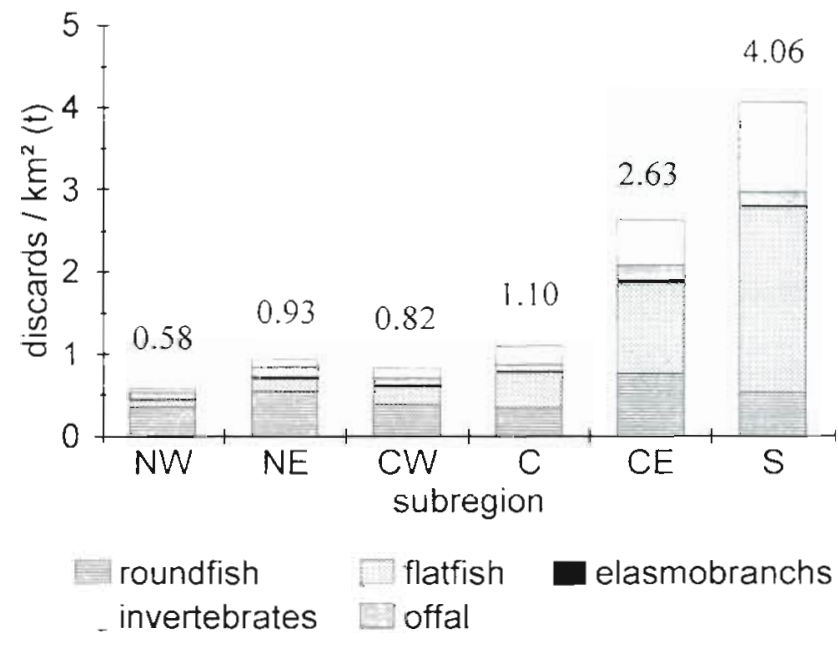

Fig. 2. Amounts of discards and offal per area in 6 subregions in the North Sea

Using the specific values for the energy content of the different discard items, a total calorific value of $3.4 \times$ $10^{12} \mathrm{~kJ}$ results (Table 5 ).

Camphuysen et al. (1995) estimated the number of scavenging seabirds in the North Sea at between 1.4 and 3.4 million birds in winter and between 3.0 and 6.0 million birds in autumn. The percentage of individuals known to feed regularly on fishery waste comprises $66 \%$ of the total North Sea avifauna in summer and $53 \%$ in winter. Expressed in biomass, scavengers account for $66 \%$ of the total seabirds-at-sea biomass in summer and $52 \%$ in winter (numbers of birds from Skov et al. 1995, body mass values from Bezzel 1985). In order to calculate the number of scavenging seabirds which could be sustained solely by fishery waste in the North Sea, we first assumed that the relative abundances of the most common species would be similar to those found by Camphuysen et al. (1995). We then estimated the energy requirements of an individual of each species (see 'Methods' for assumptions). Correcting by the mean assimilation efficiencies for fish and invertebrates by seabirds as stated in the
'Methods', the total energy available for birds in the North Sea is estimated at $2.5 \times 10^{12} \mathrm{~kJ}$. This amount was then split up according to the respective abundances and energy requirements of the bird species. Consequently, the number of seabirds that could potentially be supported by fishery waste is presented in Table 6 and amounts to 5.9 million individuals in an average scavenger community (these figures assume that all offal and discarded organisms were consumed by seabirds, which was actually the case in some discard experiments). The largest fraction of seabirds is supported by fishery waste in subregion $\mathrm{S}$, the smallest fraction in subregion CW (Table 6).

On a North Sea scale, fishery waste is sufficiently available to satisfy the energy demands of all scavenging species (Table 7). The distributions of both discards and seabirds are, however, different from each other Therefore, in subregions NW and CW, discards and vifd are nol numerous enough to balance the energy budgets of all scavengers. In contrast, this is possible in all other subregions, especially in CE and $S$.

Such calculations presuppose that discards and offal are evenly available in time. Although difficult to show, this does not appear to be the case. For example, in beam trawl fisheries in the southeastern North Sea, the highest catches of sole were obtained by small German trawlers close to the coast in the second quarter of the year, as was the case for large Dutch trawlers operating further off the coast in the third quarter (S. Garthe \& U. Damm unpubl.). Landing statistics of other fish species suggest that, in general, catches and amounts discarded fluctuate considerably between seasons.

Furthermore, even for a large number of seabirds, it is often not possible to swallow the whole bulk of fish, offal and invertebrates when discharged. This can be due to the high amount of waste thrown overboard within a short period of time or due to immediately sinking items (sea urchins, hermit crabs Pagurus bernhardus), but also due to ship manoeuvring, the avoidance distance of the birds from the ship etc., all of which prevent the birds from consuming the total amount discarded.

Table 5. Energetic equivalents $\left(\times 10^{9} \mathrm{~kJ}\right)$ of discards and offal in 6 subregions in the North Sea. For sources of energetic equivalents see Table 2

\begin{tabular}{|c|c|c|c|c|c|c|}
\hline Subregion & Roundfish & Flatfish & Elasmobranchs & $\begin{array}{c}\text { Benthic } \\
\text { invertebrates }\end{array}$ & Offal & All \\
\hline NW & 274 & 53 & 14 & 16 & 106 & 463 \\
\hline $\mathrm{NE}$ & 266 & 57 & 13 & 17 & 103 & 456 \\
\hline $\mathrm{CW}$ & 133 & 60 & 6 & 16 & 54 & 269 \\
\hline C & 236 & 246 & 11 & 61 & 105 & 659 \\
\hline $\mathrm{CE}$ & 238 & 273 & 11 & 68 & 108 & 698 \\
\hline$S$ & 144 & 509 & 5 & 123 & 90 & 871 \\
\hline Total & 1291 & 1198 & 60 & 301 & 566 & 3416 \\
\hline
\end{tabular}


Table 6. Calculation of the number of seabirds theoretically supported by discards and offal in the North Sea. Relative abundances of species were derived from the estimates given by Camphuysen et al. (1995). Base values for energetics of seabirds and calorific values of discard items are given in the text. Values in this table are rounded. Number of seabirds supported in the 6 subregions: NW, 800000; NE, 800000; CW, 500000; C, $1100000 ; \mathrm{CE}, 1200000 ; \mathrm{S}, 1500000$

\begin{tabular}{|c|c|c|c|c|}
\hline Species & $\begin{array}{c}\text { Relative } \\
\text { abundance }\end{array}$ & $\begin{array}{l}\text { Yearly energy } \\
\text { requirement per } \\
\text { individual } \\
(\mathrm{kJ})\end{array}$ & $\begin{array}{l}\text { Total energy of fishery } \\
\text { waste divided according } \\
\text { to relative abundance } \\
\text { and energy requirement } \\
\text { of species (in million } \mathrm{kJ} \text { ) }\end{array}$ & $\begin{array}{l}\text { Number of } \\
\text { individuals } \\
\text { supported }\end{array}$ \\
\hline Fulmar Fulmarus glacialis & 151 & 414700 & 1315700 & 3200000 \\
\hline Northern gannet Morus bassanus & 10 & 1179900 & 247900 & 210000 \\
\hline Great skua Catharacta skua & 1 & 663100 & 13900 & 21000 \\
\hline Common gull Larus canus & 4 & 245200 & 20600 & 84000 \\
\hline Lesser black-backed gull Larus fuscus & 6 & 419300 & 52800 & 130000 \\
\hline Herring gull Larus argentatus & 32 & 525700 & 353400 & 670000 \\
\hline Great black-backed gull Larus marinus & 12 & 722500 & 182200 & 250000 \\
\hline Black-legged kittiwake Rissa tridactyla & 64 & 233100 & 313400 & 1300000 \\
\hline Total & & & 2500000 & 5900000 \\
\hline
\end{tabular}

Table 7 Energetic requirements of scavenging seabird species and energetic equivalents of discards in the North Sea $\left(\times 10^{9} \mathrm{~kJ}\right)$. For assumptions and base values see text and Tables 5 and 6

\begin{tabular}{|lccc|}
\hline Subregion & $\begin{array}{c}\text { Energetic } \\
\text { requirements } \\
\text { of scavengers } \\
\text { (= required) }\end{array}$ & $\begin{array}{c}\text { Energetic } \\
\text { equivalents } \\
\text { of discards } \\
\text { (= available) }\end{array}$ & $\begin{array}{c}\text { Index: } \\
\text { required/ } \\
\text { available }\end{array}$ \\
\hline $\mathrm{NW}$ & 899 & 463 & 1.9 \\
$\mathrm{NE}$ & 312 & 456 & 0.7 \\
$\mathrm{CW}$ & 364 & 269 & 1.4 \\
$\mathrm{C}$ & 322 & 659 & 0.5 \\
$\mathrm{CE}$ & 120 & 698 & 0.2 \\
$\mathrm{~S}$ & 175 & 871 & 0.2 \\
Total & 2192 & 3416 & 0.6 \\
\hline
\end{tabular}

\section{Quantities of discards and offal consumed by seabirds}

The proportions of fishery waste consumed by seabirds varied between discard types and areas and with season (Table 8). Overall, offal and roundfish were consumed in the highest percentages. Flatfish, elasmobranchs and benthic invertebrates were taken only in minor amounts. Using the percentages for the different subregions listed in Table 8 , the mass of discards and offal consumed by birds during our study amounted to slightly more than $300000 \mathrm{t}$ in the whole North Sea: $55000 \mathrm{t}$ of offal, $206000 \mathrm{t}$ of roundfish, $38000 \mathrm{t}$ of flatfish, $2000 \mathrm{t}$ of elasmobranchs and $9000 \mathrm{t}$ of benthic invertebrates. Summed up, $39 \%$ of all discard items theoretically available is consumed by birds.

Generally, beam trawl fisheries discharge discards at the highest rates of all fishing fleets. Because of the clear dominance of flatfish in the discard fraction of this fishery, seabirds have to select carefully the few roundfish or have to take the less favoured flatfish (Tables $8 \& 9$ ). The opposite holds true for pelagic and gadid fisheries: there, the amounts of discards are less, but the type of discard available is more appropriate for seabirds.

The consumption percentages of discards given in Table 8 are of the same magnitude as results of previous studies (Table 9). However, discard experiments on board commercial trawlers (Hudson \& Furness 1988, Camphuysen 1994) suggest slightly lower proportions of discards consumed in the northern North Sea but not in the southern North Sea if compared to fishery research vessels (e.g. Garthe 1993, Garthe \& Hüppop 1994). Hence, experiments on research vessels will probably lead to an overestimate of consumption percentages because items were mostly discarded one after the other and not only when normal discarding took place. Thus, birds feeding in such situations had no choice between different types of fish. Also, rapidly sinking particles were consumed less frequently when discarding took place on a larger scale. The rather small differences between experiments on research vessels and commercial trawlers suggest, however, that the values obtained during our study are of the correct order of magnitude. Further studies could improve the consumption percentages by work on commercial trawlers.

\section{DISCUSSION}

The amounts of fish and other organisms discharged into the North Sea are considerable. This becomes evident if the values are compared with the total biomass 
Table 8. Percentage of experimental discards and offal consumed by birds in 6 subregions (all seasons) and 4 seasons (all subregions), respectively, in the North Sea (from Camphuysen et al. 1995, modified)

\begin{tabular}{|c|c|c|c|c|c|c|}
\hline & Roundfish & Flatfish & Elasmobranchs & $\begin{array}{c}\text { Benthic } \\
\text { invertebrates }\end{array}$ & $\begin{array}{l}\text { Offal } \\
\text { size }\end{array}$ & Sample \\
\hline \multicolumn{7}{|l|}{ Subregion } \\
\hline NW & 90 & 28 & 12 & 9 & 99 & 9132 \\
\hline $\mathrm{NE}$ & 89 & 41 & 12 & 3 & 98 & 3281 \\
\hline $\mathrm{CW}$ & 84 & 32 & 12 & 1 & 92 & 5316 \\
\hline $\mathrm{C}$ & 75 & 14 & 12 & 1 & 90 & 8519 \\
\hline $\mathrm{CE}$ & 63 & 10 & 12 & 3 & 54 & 3396 \\
\hline S & 71 & 8 & 12 & 4 & 100 & 1200 \\
\hline \multicolumn{7}{|l|}{ Season } \\
\hline Winter & 92 & 35 & 12 & 17 & 100 & 6028 \\
\hline Spring & 76 & 22 & 12 & 8 & 94 & 10354 \\
\hline Summer & 70 & 10 & 12 & 3 & 94 & 8526 \\
\hline Autumn & 82 & 20 & 12 & 3 & 97 & 5936 \\
\hline Sample size & 21848 & 2345 & 34 & 902 & 5715 & 30844 \\
\hline
\end{tabular}

Table 9. Other discard experiments in the North Sea. Consumption rates by birds are given for roundfish, flatfish, offal and invertebrates. CT: commercial trawler; RV: research vessel

\begin{tabular}{|c|c|c|c|c|c|c|c|c|c|c|c|c|c|}
\hline \multicolumn{2}{|c|}{ Roundfish } & \multicolumn{2}{|c|}{ Flatfish } & \multicolumn{2}{|c|}{ Offal } & \multicolumn{2}{|c|}{ Invertebrates } & \multirow{2}{*}{\multicolumn{2}{|c|}{$\begin{array}{l}\text { Vessel Area } \\
\text { type }\end{array}$}} & \multirow[t]{2}{*}{ Time } & \multirow[t]{2}{*}{ Season } & \multirow[t]{2}{*}{ Year } & \multirow[t]{2}{*}{ Source } \\
\hline$\%$ & $\mathrm{n}$ & $\%$ & $\mathrm{n}$ & $\%$ & $n$ & $\%$ & $\mathrm{n}$ & & & & & & \\
\hline $58^{\mathrm{a}}$ & 6423 & $5^{\mathrm{a}}$ & 1182 & - & - & - & - & CT & Around Shetland & Day & Summer & $1984-1985$ & 1 \\
\hline 83 & 208 & 67 & 76 & - & - & - & - & RV & Off SW Norway & Day & Summer & 1990 & 2 \\
\hline 85 & 430 & 30 & 56 & - & - & 56 & 311 & RV & Helgoland area & Day & Winter & $1991-1992$ & 3 \\
\hline 79 & 909 & 30 & 1259 & 83 & 296 & 11 & 79 & RV & Helgoland area & Day & Summer & $1991-1992$ & 3 \\
\hline 84 & 13594 & 8 & 397 & - & - & - & - & RV & North Sea & Day & Summer & 1992 & 4 \\
\hline 86 & 7 & 16 & 19 & - & - & - & - & RV & Skagerrak/Kattegat & Day & Winter & 1993 & 2 \\
\hline 48 & 52 & 24 & 79 & - & - & - & - & RV & Skagerrak/Kattegat & Night & Winter & 1993 & 2 \\
\hline 69 & 258 & 13 & 67 & 74 & 608 & - & - & RV & Southern North Sea & Day & Winter & 1992 & 5 \\
\hline 85 & 642 & 34 & 387 & 94 & 642 & 0.3 & ? & CT & West of Helgoland & Day & Summer & 1993 & 6 \\
\hline 71 & 1101 & 31 & 1044 & 66 & 1217 & 0.3 & 2540 & $\mathrm{CT}$ & Southern North Sea & Day & Summer & 1993 & 7 \\
\hline \multicolumn{14}{|c|}{$\begin{array}{l}\text { a } \% \text { values in Hudson \& Furness (1988) are minimum \% consumed (since many discards were of 'unknown' fate, probably } \\
\text { many of these were also consumed) }\end{array}$} \\
\hline \multicolumn{14}{|c|}{$\begin{array}{l}\text { Sources: (1) Hudson \& Furness (1988); (2) Garthe \& Hüppop (1993); (3) Garthe (1993); (4) Garthe \& Hüppop (1994); (5) Camp- } \\
\text { huysen (1993b); (6) Camphuysen (1993a); (7) Camphuysen (1994), includes (6) }\end{array}$} \\
\hline
\end{tabular}

of fish and the total landings from the North Sea: fish discards (576500 $\mathrm{t} \mathrm{yr}^{-1}$; Table 4 ) represent roughly $4 \%$ of the total biomass of fish and $22 \%$ of the total landings of fish from the North Sea (Table 1).

It is most obvious that discards and offal provide an enormous amount of food which is exploited heavily by seabirds in all areas of the North Sea and throughout the year. The importance of fishery waste becomes evident if compared to natural sources of food. Thus, the mass of fishery waste taken by birds more than equals the $265000 \mathrm{t}$ of live fish calculated to be consumed by all seabirds in the North Sea, being twice as high as the mass of 'other food' including zooplankton, cephalopods and terrestrial food (Anonymous 1994d). Most interest- ing, the distribution of discard density (Fig. 2) stands in contrast to the distribution of scavenging seabirds at sea, which occur in the highest densities in the northwestern North Sea more or less the whole year round (Camphuysen et al. 1995, Skov et al. 1995). The reason for this difference is that the northwestern North Sea holds the majority of the breeding pairs of most scavenging species, especially cliff-nesting species such as northern fulmar and black-legged kittiwake (Dunnet et al. 1990). The southern and southeastern part of the North Sea is well suited for flatfish trawling due to its sandy sediment and hence provides large amounts of discards. Considering the numbers of seabirds theoretically sustained by fishery waste, it becomes clear that discards and offal 
may easily support all scavenging seabirds in the southern and southeastern subregion, but only half in the northwestern subregion (Table 7). The relatively high percentages of discards consumed demonstrates that discard consumption must comprise a very important part of the diet of the scavenging species

Many findings suggest that wholly pelagic bird species such as northern fulmar, northern gannet and black-legged kittiwake do not utilize fishery waste to the same extent as large gulls (Camphuysen et al. 1995). This may indicate that these gulls are more dependent on this type of food than the pelagic species. Furness \& Hislop (1981) showed that discards formed up to $70 \%$ of the diet of adult great skuas breeding in Shetland and $28 \%$ of chick diet even when their preferred prey, sandeel Ammodytes marinus, was abundant. When sandeel abundance declined in the late 1980 s, discards formed up to $82 \%$ of adult diet and $77 \%$ of chick diet (Hamer et al. 1991). Although breeding success was much reduced in the absence of sandeels, the survival of chicks must then have been largely dependent on the supply of discards (Furness 1987). Oro et al. (1995a, b) demonstrated that the breeding success of both Audouin's gull Larus audouinii and yellow-legged gull Larus cachinnans differed significantly between years with different trawling activity in the Ebro Delta, NE Spain. Both species of gull compensated partly for the cessation in food supply (discards) by switching to other types of food after a trawl moratorium took place. However, except for great skuas on Shetland and the large gulls in the Ebro Delta in NE Spain, we have only poor evidence that fishery waste forms the essential part of the diet of any other population of seabirds. Nevertheless, the availability of discards is believed to affect feeding strategies of the scavengers. For example, Blaber et al. (1995) suspected that the greater availability of discards of similar taxa may have led to greater overlap in the diets of the seabird species of the Northern Great Barrier Reef, Australia. Also, the diet of a variety of species has changed due to the supply of discards, which holds true also for the North Sea (e.g. Hudson 1986, Camphuysen 1993c). Since fisheries are carried out throughout the whole study area and throughout the whole year, interrupted only locally in the vicinity of strong gales, we are rarely able to demonstrate any effects of fishing activities on feeding ecology and reproductive output of discard utilizers. This might be the reason for the weak link between studies showing the utilization of discards at sea and studies focusing on possible effects of fishing activities.

What can wo conclude for future srenarios of fisheries practice in the North Sea? Two ways of reducing discards are likely to occur in the forthcoming years (cf. Furness 1992, Anonymous 1994e, Hubold 1994): firstly, a general reduction in fishing effort and hence a general reduction in discards, and secondly an increase in the mesh size used in fishing gears. These measures will have different effects on scavengers. A general reduction would lead to more interactions and thus would probably shift the foraging efficiency further in the direction of the species with the highest potential for kleptoparasitism. In other words, black-legged kittiwake, other small gulls and northern fulmars (cf. Camphuysen et al. 1995) could suffer greatest. An increase in mesh size does not necessarily decrease the amount of smaller fish caught, due to counteracting measures taken by fishermen as has been shown by Reeves et al. (1992). However, if this measure is obeyed accurately, the proportion and amount of small fish would decrease considerably: Furness (1992) calculated reductions in the mass of discarded fish of $52 \%$ (haddock) and $65 \%$ (whiting) if the mesh size increased from 90 to $120 \mathrm{~mm}$ in North Sea fishing fleets. This increase would principally reduce the small discards (Furness 1992). Hence, a deterioration of the feeding conditions for, in particular, black-legged kittiwake, black-headed gull and common gull, which utilize the smallest fish from the discards (Camphuysen et al. 1993, Garthe \& Hüppop 1994), would result. Finally, both measures could reduce feeding profitabilities for immature individuals since adults are generally more successful than immature individuals of the same species (see Wunderle 1992 for review). Furthermore, immature individuals would perhaps be forced to switch to less favourable lengths of discards (Garthe 1993). In conclusion, immature individuals, especially birds in their first year of life, could suffer from higher mortality. Nevertheless, measures to reduce discards are highly desirable in spite of these apparent disadvantages for birds

Summarizing, the practise of discarding unwanted fish and invertebrates at sea has a significant effect on seabirds. Not only is the amount of discards high when compared to the standing stock and the total landings of fish, but also fishery waste comprises an important, sometimes even essential, part of the diet of several seabird species.

Acknowledgements. This paper is based upon fieldwork and analyses of the project 'Consumption of discards by seabirds in the North Sea' which was financially supported by the European Commission (EC DG XIV research contract BIOECO/93/10). We thank all participants from the following institutions involved in the project: Nederlands Instituut voor Onderzoek der Zee (Den Burg/Texel, The Netherlands), Division of Environmental and Evolutionary Biology, Glasgow University (Glasgow, UK), Inselstation Helgoland des Instituts für Vogelforschung (Helgoland, Germany), Joint Nature Conservation Committee (Aberdeen, UK), Norsk Institutt for

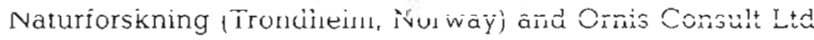
(Kobenhavn, Denmark). NIOZ publ no. 3038. O. Hüppop, Helgoland, and W. Weber, Kiel, improved earlier versions of this paper by helpful discussions. 


\section{LITERATURE CITED}

Anorjymous (1990) Report of the International North Sea, Skagerrak and Kattegat Bottom Trawl Survey Working Group. ICES, CM 1990/H:3

Anonymous (1992) ICES Fisheries Statistics. Vol. 73. Int Coun Explor Sea, Kobenhavn

Anonymous (1993a) Report of the Working Group on the assessment of demersal stocks in the North Sea and Skagerrak. ICES, CM 1993/Assess:5

Anonymous (1993b) Report of the Working Group on the assessment of mackerel, horse mackerel, sardine, and anchovy. ICES, CM 1993/Assess:19

Anonymous (1994a) Report of the Working Group on the assessment of demersal fish stocks in the North Sea and Skagerrak. ICES, CM 1994/Assess:6

Anonymous (1994b) Report of the Working Group on the assessment of norway pout and sandeel. ICES, CM 1994/ Assess: 7

Anonymous (1994c) Herring assessment Working Group for the area south of $62^{\circ} \mathrm{N}$. ICES, CM 1994/Assess: 13

Anonymous (1994d) Report of the Study Group on seabird/fish inieractions. ICES, CM 1994/L:3

Anonymous (1994e) Report of the Working Group on ecosystem effects of fishing activities. ICES, CM 1994/Assess/ ENV:1

Anonymous (1995) Report of the Working Group on the assessment of demersal fish stocks in the North Sea and Skagerrak. ICES, CM 1995/Assess:8

Berghahn R (1990) On the potential impact of shrimping on trophic relationships in the Wadden Sea. In: Barnes $M$, Gibson RN (eds) Trophic relationships in the marine environment. Proc 24th Eur Mar Biol Symp, Oban 1989. Aberdeen Univ Press, Aberdeen, p 130-140

Bezzel E (1985) Kompendium der Vögel Mitteleuropas. Nonpasseriformes-Nichtsingvögel. Aula, Wiesbaden

Birt-Friesen VL, Montevecchi WA, Cairns DK, Macko SA (1989) Activity-specific metabolic rates of free-living northern gannets and other seabirds. Ecology 70:357-367

Blaber SJM, Milton DA, Smith GC, Farmer MJ (1995) Trawl discards in the diets of tropical seabirds of the northern Great Barrier Reef, Australia. Mar Ecol Prog Ser 127:1-13

Brekke B, Gabrielsen GW (1994) Assimilation efficiency of adult kittiwakes and Brünnich's guillemots fed capelin and arctic cod. Polar Biol 14:279-284

Bryant DM, Furness RW (1995) Basal metabolic rates of North Atlantic seabircs. Ibis 137:219-226

Camphuysen CJ (1993a) Fourageermogelijkheden voor zeevogels in de boomkorvisserij: een verkennend onderzoek. Sula $7: 81-104$

Camphuysen CJ (1993b) Een verkennend onderzoek: de exploitatie van op zee overboord geworpen vis en snijafval door zeevogels. Het Vogeljaar 41:106-114

Camphuysen CJ (1993c) Scavenging seabirds behind fishing vessels in the Northeast Atlantic with emphasis on the southern North Sea. NIOZ-rapport 1993-1, Netherlands Institute for Sea Research. Texel

Camphuysen, CJ (1994) Flatfish selection by herring gulls Larus argentatus and leiser black-backed gulls Larus fuscus scavenging at commercial beamtrawlers in the southern North Sea. Veth J Sea Res 32:91-98

Camphuysen CJ, Calvo B, Durinck J, Ensor K, Follestad A, Furness RW, Garthe S, Leaper G, Skov H, Tasker ML, Winter CJN (1995) Consumption of discards by seabirds in the North Sea. Final report EC DG XIV research contract BIOECO/93/10. NIOZ-rapport 1995-5, Netherlands Institute for Sea Research, Texel
Camphuysen CJ, Ensor K, Furness RW, Garthe S, Hüppop O, Leaper G, Offringa $H$, Tasker ML (1993) Seabirds feeding on discards in winter in the North Sea. EC DG XIV research contract 92/3505. NIOZ-rapport 1993-8. Netherlands Institute for Sea Research, Texel

Castro G, Stoyan N, Myers JP (1989) Assimilation efficiency in birds: a function of taxon or food type? Comp Biochem Physiol 92A:271-278

Corten A (1991) Discard sampling programme for the North Sea. Dutch participation (2nd part). Report Pelvis 91-402, Netherlands Institute for Fishery Investigations, Ijmuiden

Cummins KW, Wuycheck JC (1971) Caloric equivalents for investigations in ecological energetics. Mitt Int Verein Limnol 18:1-151

Daan N (1975) Consumption and production in the North Sea cod, Gadus morhua: an assessment of the ecological status of the stock. Neth J Sea Res 9:24-55

Daan N, Bromley PJ, Hislop JRG, Nielsen NA (1990) Ecology of North Sea fish. Neth J Sea Res 26:343-386

Dunnet GM, Furness RW, Tasker ML, Becker PH (1990) Seabird ecology in the North Sea. Neth J Sea Res 26: $387-425$

Ehrich S (1994) Die Bewirtschaftung des Nordseekabeljau unter der Gemeinsamen Fischereipolitik der EU. Inform Fischwirt 41:118-124

Evans SM, Hunter JE, Elizal, Wahju RI (1994) Composition and fate of the catch and bycatch in the Farne Deep (North Sea) Nephrops fishery. ICES J Mar Sci 51:155-168

Fonds $M$ (1994) Catch composition of $12-m$ beam trawl and 4-m beam trawl for sole fishing. In: de Groot SJ, Lindeboom HJ (eds) Environmental impact of bottom gears on benthic fauna in relation to natural resources management and protection of the North Sea. NIOZ-rapp 1994-11, RIVO-DLO rep C026/94:95-130. Netherlands Institute for Sea Research, Texel

Furness RW (1987) Effects of changes in whitefish net-mesh size on scavenging seabird ecology. NCC Chief Scientist Directorate Rep 799

Furness RW (1992) Implications of changes in net mesh size fishing effort and minimum landing size regulations in the North Sea for seabird populations. JNCC report 133

Furness RW, Hislop JRG (1981) Diets and feeding ecology of great skuas Catharacta skua during the breeding season in Shetland. J Zool Lond 195:1-23

Furness RW, Hudson AV, Ensor K (1988) Interactions between scavenging seabirds and commercial fisheries around the British Isles. In: Burger $\mathrm{J}$ (ed) Seabirds and other marine vertebrates: competition, predation and other interactions. Columbia University Press, New York, p 240-268

Garthe S (1993) Quantifizierung von Abfall und Beifang der Fischerei in der sudöstlichen Nordsee und deren Nutzung durch Seevögel. Hamburger Avifaun Beitr 25: $125-237$

Garthe S, Hüppop O (1993) Gulls and fulmars following ships and feeding on discards at night. Ornis Svecica 3:159-161

Garthe S. Hüppop O (1994) Distribution of ship-following seabirds and their utilization of discards in the North Sea in summer. Mar Ecol Prog Ser 106:1-9

Hamer KC, Furness RW, Caldow RWG (1991) The effects of changes in food availability on the breeding ecology of great skuas Catharacta skua in Shetland. J Zool Lond 223: $175-188$

Hislop JRG, Harris MP, Smith JGM (1991) Variation in the calorific value and total energy content of the lesser sandeel (Ammodytes marinus) and other fish preyed on by seabirds. J Zool Lond 224:501-517

Hubold G (1994) Maßnahmenkatalog für eine ausgewo- 
genere und rationellere Bewirtschaftung der von der deutschen Fischerei genutzten Fischereiressourcen im EG Meer. Inform Fischwirt 41:3-18

Hudson AV (1986) The biology of seabirds utilising fishery waste in Shetland. PhD thesis, Univ of Glasgow

Hudson AV, Furness RW (1988) Utilization of discarded fish by scavenging seabirds behind white fish trawlers in Shetland. J Zool Lond 215:151-166

Jackson S (1986) Assimilation efficiencies of white-chinned petrels (Procellaria aequinoctialis) fed different prey. Comp Biochem Physiol 85A:301-303

Jensen H, Emslie D, Coull K (1994) Discards of fish species of no or very little economic interest. European Commission, study contract 92/3508. Danish Institute for Fisheries and Marine Research, Charlottenlund

Kirkegaard E (1991) Discard sampling programme for the North Sea. Danish participation (2nd part). EC DG XIV study contract 1990/9. Danish Institute for Fisheries and Marine Research, Charlottenlund

Kirkegaard E, Poulsen FD (1990) Discard sampling programme for the North Sea. Danish participation. EC DG XIV/b/1 study contract 1989/8. Danish Institute for Fisheries and Marine Research, Charlottenlund

Lloyd C, Tasker ML, Partridge K (1991) The status of seabirds in Britain and Ireland. Poyser, London

Oro D, Bosch M, Ruiz X (1995a) Effects of a trawling moratorium on the breeding success of the yellow-legged gull Larus cachinnans. Ibis 137:547-549

Oro D, Jover L, Ruiz X (1995b) The effects of trawl moratorium on some breeding parameters of Audouin's gull Larus audouinii in the Ebro Delta, NE Spain. In: Tasker ML (ed) Threats to seabirds. Proc 5th Int Seabird Group Conf. Glasgow Seabird Group, Sandy, p 33

Reeves SA, Armstrong DW, Fryer RJ, Coull KA (1992) The effect of mesh size, cod-end extension length and cod-end diameter on the selectivity of Scottish trawls and seines. ICES J Mar Sci 49:279-288

Sahrhage D (1958) Untersuchungen über die Vernichtung untermaßiger Schellfische durch die deutsche Herings-

This article was submitted to the editor schleppnetzfischerei in der Nordsee. Ber Dtsch Wiss Komm Meeresforsch 15:105-131

Sahrhage D (1959) Untersuchungen über den Anteil untermaßiger Wittlinge in den Fängen der deutschen Heringsschleppnetzfischerei in der Nordsee. Ber Dtsch Wiss Komm Meeresforsch 15:335-356

Sidwell VD (1981) Chemical and nutritional composition of finfishes, whales, crustaceans, mollusks and their products. NOAA-TM-NMFS-F/SEC-11

Skov H, Durinck J, Leopold MF, Tasker ML (1995) Important bird areas for seabirds in the North Sea including the Channel and the Kattegat. BirdLife International, Cambridge

Sparholt $H$ (1990) An estimate of the total biomass of fish in the North Sea. J Cons Int Explor Mer 46:200-210

Tiews K (1983) Über die Veränderungen im Auftreten von Fischen und Krebsen im Beifang der deutschen Garnelenfischerei während der Jahre 1954-1981-ein Beitrag zur Ökologie des deutschen Wattenmeeres und zum biologischen Monitoring von Ökosystemen im Meer. Arch FischWiss 34 (Beih 1): $1-156$

Tiews K, Wienbeck H (1990) Grundlagenmaterial zu 35Jahrestrend (1954-1988) der Häufigkeit von 25 Fisch- und Krebstierbeständen an der Deutschen Nordseeküste' Veröff Inst Küst Binnenfisch Hamburg 103:1-64

van Beek FA (1990) Discard sampling programme for the North Sea. Dutch participation. Report DEMVIS 90-303, Netherlands Institute for Fishery Investigations, Ijmuiden

Walter U, Becker PH (1994) The significance of discards from the brown shrimp fisheries for seabirds in the Wadden Sea-preliminary results. Ophelia, Suppl 6:253-262

Weber W (1995) Discard-Problematik aus fischbestandskundlicher Sicht. Dt Hydrogr Z, Suppl 2:101-108

Weigelt C (1891) Die Abfälle der Seefischerei. Experimentelle Untersuchungen über deren Natur, Menge, Verarbeitung und Verwerthung. Mitt Sekt Küsten- u Hochseefisch 1891 , Sonderbeilage 2

Wunderle JM Jr (1992) Age-specific foraging proficiency in birds. Curr Ornithol 9:273-324

Manuscript first received: October 9, 1995

Revised version accepted: February 15, 1996 